\title{
Distribution and Origin of Aliphatic Hydrocarbons in Surface Sediments of Strategical Areas of the Western Moroccan Mediterranean Sea
}

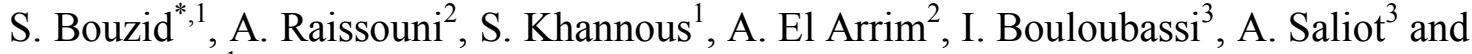 \\ H. Er-Raioui ${ }^{1}$
}

${ }^{I}$ Equipe « Géosciences et Environnement 》 - Département des Sciences de la Terre - Faculté des Sciences et Techniques à Tanger - Ancienne route de l'aviation, BP. 416, Tanger, Maroc

${ }^{2}$ Laboratoire "Environnement, Océanologie et Ressources Naturelles" (LEORN) - Equipe de Recherche en Environnement Marin et Risques Naturels (EREMRN) -Département de Sciences de la terre - Faculté des Sciences et Techniques à Tanger, Ancienne route de l'aviation, BP:416, Tanger, Maroc

${ }^{3}$ L.O.C.E.A.N., UMR CNRS 7159, IPSL/IRD/UPMC/MNHN, Université Pierre et Marie Curie, Case courrier 100, 4 Place Jussieu, 75252 Paris Cedex 05, France

\begin{abstract}
This work focuses on the assessment of aliphatic hydrocarbons in sediments collected from the western Moroccan Mediterranean coasts. Two zones have been chosen for this study. Zone 1 corresponds to Tangier's bay and zone 2 corresponding to the fringe between Kabila and Kaâ Srass. The aliphatic hydrocarbons were extracted and analysed using chromatographic techniques (GC/FID and GC/MS). The results showed a more important accumulation of aliphatic hydrocarbons in Tangier's bay if compared with zone 2. Levels ranged within 128.8 to $340.31 \mu \mathrm{g} / \mathrm{g}$ dry weight, with two exceptions 611.72 and $648.16 \mu \mathrm{g} / \mathrm{g}$ dry weights and from 5.25 to $22.71 \mu \mathrm{g} / \mathrm{g}$ dry weights, for zones 1 and 2 , respectively. Moreover, the aliphatic hydrocarbons distribution proves to be strongly influenced by the nearness to input sources and by oceanographic and hydrodynamic conditions. Thus, two distribution patterns were observed corresponding to the two areas studied. Furthermore, the examination of origin fingerprinting criteria proved the biogenic origin related to phytoplankton, bacteria and continental plant waves. The anthropogenic character of hydrocarbons was also evidenced especially in Tangier's bay, by several chromatographic criteria and was confirmed by the presence of hopanes with predominant $\mathrm{C} 29$ and $\mathrm{C} 30 \alpha, \beta$ compounds.
\end{abstract}

Keywords: Tangier's bay, coasts Kabila-Kaâ Srass, sediments, aliphatic hydrocarbons, chemical markers, chromatographic fingerprinting.

\section{INTRODUCTION}

The semi-enclosed Mediterranean Sea appears to be subjected to important anthropogenic inputs of organic pollutants, mainly hydrocarbons, from rivers, atmosphere, coastal and shipping activities. Those compounds constitute one of the largest and most widespread types of organic pollutants. Indeed, the annual inputs of petroleum hydrocarbons in the Mediterranean are estimated to be over three quarters of a million tonnes of oil from land-based and open-sea discharges [1]. This fact constitutes a major preoccupation for the Mediterranean ecosystems known for being fragile and vulnerable to persistent pollutants. Due to their carcinogenic and mutagenic proprieties they are introduced in the US EPA and the EU priority list, mainly the group of polycyclic aromatic hydrocarbons. Furthermore, hydrocarbons possess high chemical stability and hydrophobic properties which result in enhanced accumulation and a high capacity for distribution in the environment [2]. Consequently, a high

*Address correspondence to this author at the Equipe «Géosciences et Environnement»- Département des Sciences de la Terre - Faculté des Sciences et Techniques à Tanger - Ancienne route de l'aviation, BP. 416, Tanger, Maroc; Tél: (00212) 393939 54; Fax: (00212) 03939 39 53; E-mail: sur24@yahoo.fr interest was generated in studying their sources, distribution, transport mechanisms, environmental fate and impact, especially in coastal areas, since more than $50 \%$ of the population lives within 100 miles of the coast [2]. In fact, such regions are highly submitted to pollutants released from human activities, and thus, they are of great environmental and socio-economic concern in terms of ecosystem preservation and sustainable development.

Most surveys on the Mediterranean Sea have focused on areas in the northern shore of the Sea. Less information is available for other areas in the southern part. There is still a lack of data on this part especially for the Moroccan Mediterranean coasts. Indeed, in this area, hydrocarbons were studied and evaluated only on particles and bivalves (unpublished data). Nevertheless, there is a striking paucity of data on the occurrence hydrocarbons in sediment, a compartment that act as a sink and indicator of hydrocarbons inputs. To fill this gap, this work focuses on the study of hydrocarbons on surface sediments from the western Moroccan Mediterranean coasts.

Hydrocarbons might have been introduced in that region through riverine discharges, shipping activities, sewage disposal, transport and accidental oil spills. They might also 
have been released during pyrolysis/combustion of fossil fuels.

Two zones were chosen for this survey corresponding to Tangier's bay (Zone 1) and the littoral between Kabila and Kaâ Sras villages (Zone 2). These two zones are different from the point of view of morphology, hydrodynamics, anthropogenic contributions and diversity of pollution sources.

The bay of Tangier constitutes a relatively closed environment submitted to a limited hydrodynamic action. On the other hand, the coastal fringe between Kabila and Kaâ Srass corresponds to an open environment where the circulation plays an important role in the distribution of solid and dissolved particles and therefore of the pollutants poured in sea.

In this study, we focus especially on the assessment of aliphatic hydrocarbons and the use of several chemical markers and criteria to indicate the origin of those compounds (biogenic, petrogenic).

\section{MATERIALS AND METHODS}

\subsection{Study Area and Sampling}

The bay of Tangier (Zone 1) is situated at the Northwestern extreme of Morocco and located in the Gibraltar strait on the opening of the Mediterranean Sea over the Atlantic Ocean. It represents a maritime depression dug between two rocky capes. This bay constitutes a relatively calm environment with a constant inputs resulting from industrial and domestic discharges through 3 small rivers as well as from the harbour activities (shipping and fishing activities).

The coastal fringe between Fnidek and Kaâ Sras villages (Zone 2) is extended on more of $100 \mathrm{~km}$ and is relatively straight according to a North-South direction [3].

Along these coasts, we can observe a chain of touristic installations with two pleasance harbours and one fisheries harbour more in the south. This zone is exposed to important inputs from sewage waters emanated from the city of Tetouan and neighbouring villages. It is important to indicate the significant role of some rivers like Martil and Oued Laou in the evacuation of industrial and domestic discharges to the marine environment. This zone is also subjected to different inputs of petrogenic hydrocarbons resulting from harbours activities.

In this fringe, the swells are heavy and are directed Eastnortheast [4]. The general circulation is represented by the superposition of two masses of water, Atlantic superficial $(40$ to $60 \mathrm{~cm} / \mathrm{s})$ West-Est and Mediterranean $(30 \mathrm{~cm} / \mathrm{s})$ EastWest. In general, this zone is considered as an open environment, agitated relatively to zone 1 .

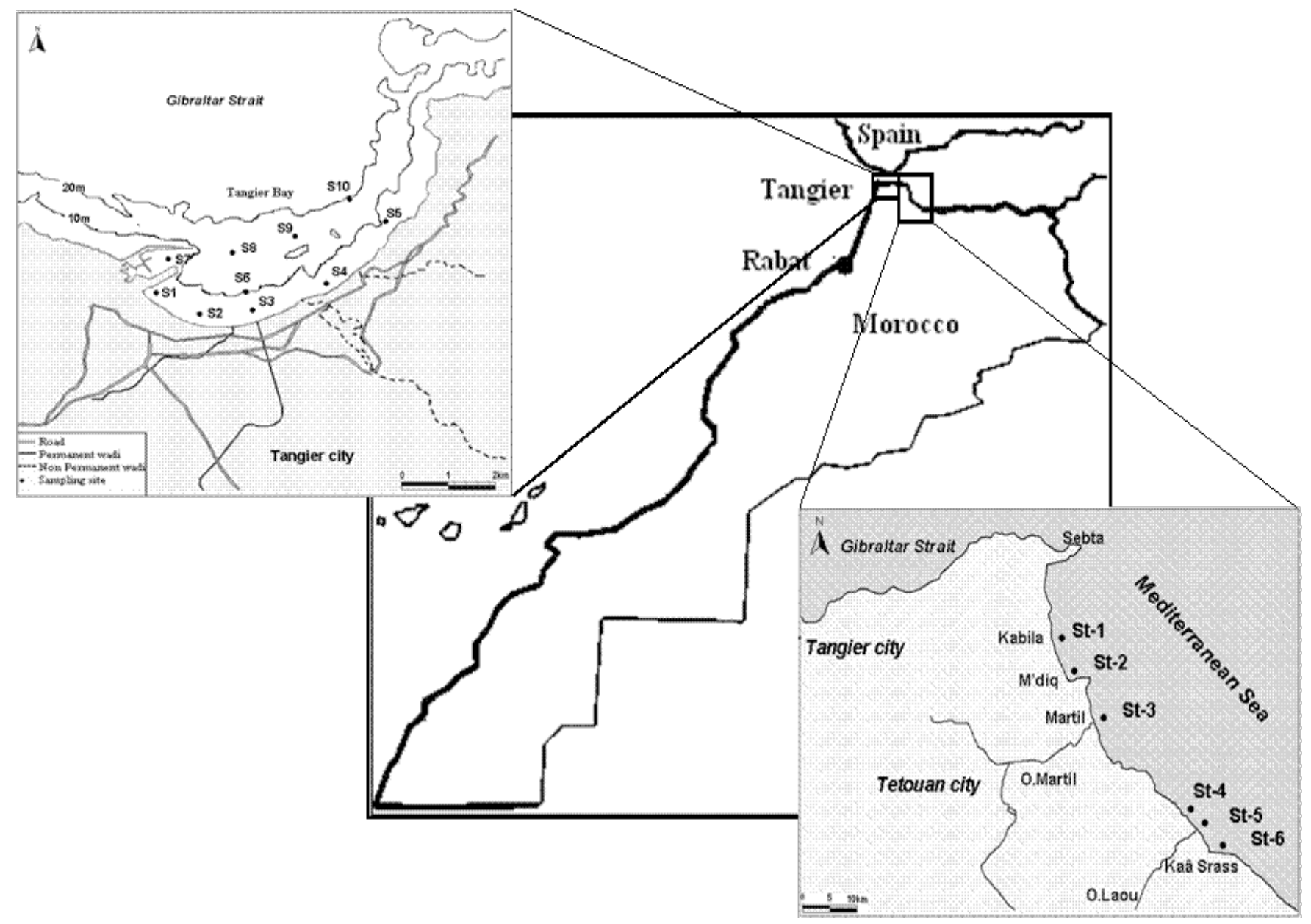

Fig. (1). Map of North-west Morocco showing sampling locations. 
Surface sediments were collected from 10 stations throughout the bay and from 6 stations along the coasts of zone 2 (Fig. 1). The sampling has been accomplished with the help of a dredge and with the assistance of a professional diver. Only the first $5 \mathrm{~cm}$ of surface were taken.

The sediment samples were conserved at low temperatures then freeze-dried until an ulterior analysis.

\subsection{Extraction and Fractionation of Hydrocarbons}

The extraction was done according to the protocol of Bligh and Dyer [5], previously modified to replace chloroform by dichloromethane. Samples were first spiked with perdeuterate internal standards (C24D50 and ParaterphenyleD10), extracted three times by sonication with a mixture of dichloromethane (DCM) and methanol (MeOH) (1:3) and then dried on $\mathrm{MgSO}_{4}$. Sulfur was removed by the addition of pieces of copper.

The extract was filtered and after that rotary evaporated under reduced pressure until near dryness and then dried under a gentle stream of nitrogen. The purification and fractionation were performed in columns $(0.8 \mathrm{~mm}$ of diameter $)$ packed with $0.4 \mathrm{~g}$ of neutral silica which had been previously activated for $1 \mathrm{~h}$ at $150^{\circ} \mathrm{C}$ and deactivated. Elution solvents for organic extract fractionation were: first, $3 \mathrm{ml}$ hexane (aliphatic hydrocarbons) followed by $9 \mathrm{ml}$ hexane/ toluene $(9: 1 \mathrm{v} / \mathrm{v})$ (aromatic hydrocarbons). All organic solvents were obtained from Merck (Darmstadt, Germany), and bi-distilled before their use.

\subsection{GC/FID and GC/MS}

The qualitative analysis of hydrocarbons was carried out using a chromatograph Delsi Model DI 200, Perichrom France equipped with a flame ionisation detector. Fractions were injected on a fused silica capillary column DB-5 MS ( $30 \mathrm{~m}, 0.25 \mathrm{~mm}$ i.d., $0.25 \mu \mathrm{m}$ film thickness), using Helium as a carrier gas. The temperature program used was as follows: Oven temperature $60^{\circ} \mathrm{C}$, heating speed $25^{\circ} \mathrm{C} / \mathrm{min}$ to $100^{\circ} \mathrm{C}$, then $2^{\circ} \mathrm{C} / \mathrm{min}$ to $310^{\circ} \mathrm{C}$ with an isotherm at $310^{\circ} \mathrm{C}$ for $70 \mathrm{~min}$.
Hydrocarbons were identified by comparison of retention times with known standards of n-alkanes, ranging from n$\mathrm{C} 15$ to $\mathrm{n}-\mathrm{C} 32$. To confirm the structure of several hydrocarbons, some samples were also analysed by chromatography-mass spectrometry (HP6890-HP5973MSD Agilent Technologies, Wilmington DE, USA), using fused-silica column (DB-5 MS, 30m, 0.25mm i.d., 0.25 $\mu \mathrm{m}$ film thickness) coated with $5 \%$ phenyl methyl siloxane. Helium was used as a carrier gas. The temperature program employed was the same as in GC/FID.

\section{RESULTS}

\subsection{Zone 1 - Tangier's Bay}

The results related to aliphatic hydrocarbons fraction and all diagnostic criteria used for origin identification, are given in Table 1.

The concentrations of aliphatic hydrocarbons varied from 128.8 to $340.31 \mu \mathrm{g} / \mathrm{g}$ dry weight, with two exceptions at two stations S2 and S7. Those latter constitute zones of maximum concentration in the bay and show high accumulations of aliphatic hydrocarbons respectively of 611.72 and 648.16 $\mu \mathrm{g} / \mathrm{g}$ dry weight.

The concentrations of aliphatic hydrocarbons in the sediments of the Tangier's bay exhibited some spatial variations (Fig. 2). It shows an important accumulation that appears in the western part of the bay, with maximum concentrations measured in S7, S2 and S1 stations. This accumulation can be the result of harbour activities and of the urban contributions via wastes of Tangier's sewages. The other stations present relatively middle concentrations in aliphatic hydrocarbons. For the axe bordering the coast (S1, S2, S3, S4 and $\mathrm{S} 5)$, an enrichment in aliphatic hydrocarbons is observed from the Eastern part to the Western part of the bay. It is probably due to the action of the main coastal flow of direction East-West present in the bay and which is responsible for the transportation and accumulation of sediment in the west part of the bay [4].

Table 1. Aliphatic Hydrocarbons Concentrations and Selected Aliphatic Diagnostic Criteria for the Sediments Collected from Tangier's Bay

\begin{tabular}{|c|c|c|c|c|c|c|c|c|c|c|c|}
\hline & NAH & T-alk & UCM & UCM/n-alk & \%UCM/NAH & Pr/Ph & C17/Pr & C18/Ph & CPI & n-C29/n-C17 & \%C>25 \\
\hline \hline S1 & 340.31 & 5.02 & 176.31 & 35.12 & 51.81 & 0.74 & 0.75 & 0.85 & 1.46 & 13.59 & 78.24 \\
\hline S2 & 611.35 & 7.96 & 480.20 & 60.30 & 78.55 & 0.21 & 4.64 & 0.30 & 0.69 & 1.43 \\
\hline S3 & 231.72 & 4.71 & 93.09 & 19.77 & 40.17 & 0.67 & 0.91 & 0.83 & 1.44 & 7.60 \\
\hline S4 & 148.02 & 1.74 & 20.09 & 11.54 & 13.57 & 0.58 & 1.17 & 1.16 & 1.43 & 76.68 \\
\hline S5 & 177.80 & 0.61 & --- & --- & ---12 & 1.19 & 1.29 & 1.46 & 1.16 & 7.40 & 58 \\
\hline S6 & 195.49 & 7.38 & 66.74 & 9.05 & 34.14 & 0.97 & 0.59 & 0.73 & 1.60 & 10.81 & 77.47 \\
\hline S7 & 648.16 & 15.60 & 406.39 & 26.05 & 62.70 & 0.42 & 10.17 & 3.47 & 1.53 & 2.81 \\
\hline S8 & 128.80 & 1.52 & 38.24 & 25.11 & 29.69 & 0.13 & 1.07 & 0.60 & 1.34 & 54.39 & 77.82 \\
\hline S9 & 140.86 & 1.39 & 131.82 & 94.58 & 93.59 & 0.51 & 3.05 & 1.22 & 1.70 & 6.95 \\
\hline S10 & 176.18 & 0.41 & --- & --- & -- & 5.95 & 0.73 & 1.58 & 1.11 & 5.63 \\
\hline
\end{tabular}




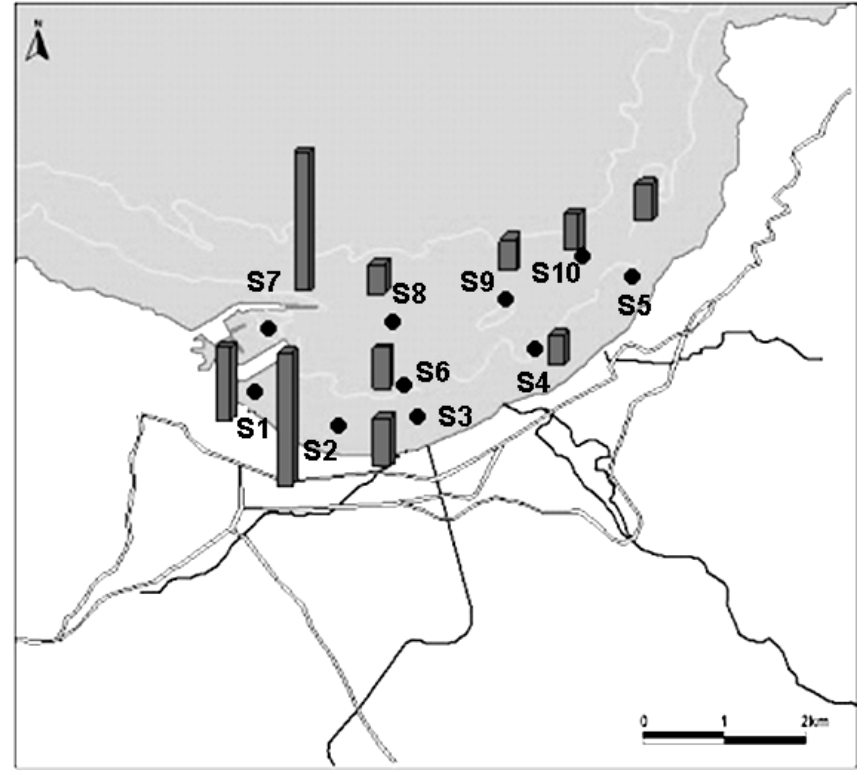

Fig. (2). Map of Tangier's bay showing spatial distribution of aliphatic hydrocarbons rates presented in logarithmic scale.

\subsection{1. $U C M$}

All chromatograms showed the presence of unresolved compounds named also UCM except for two stations S5 and S10. These molecules are resistant to the biodegradation and thus accumulate in the sediments [6]. The presence of such compounds in high concentrations $(20$ to $480 \mu \mathrm{g} / \mathrm{g}$ ) constitutes a criterion to establish a long term oil contamination. These observations are also confirmed by the UCM/n-alk ratio (9-94) (Table 1) [7]. Indeed, such values indicate a chronic contamination by degraded oil [8].

\subsection{2. $N$-Alkanes}

The chromatograms showed n-alkanes distribution, from $\mathrm{n}-\mathrm{C} 15$ to $\mathrm{n}-\mathrm{C} 38$ for most samples. The concentrations of total n-alkanes varied from 0.41 to $15.6 \mu \mathrm{g} / \mathrm{g}$.

The range of the lower molecular weight compounds showed the important presence of $\mathrm{n}-\mathrm{C} 17$ and/or the $\mathrm{n}-\mathrm{C} 15$, with a light predominance of the compounds with odd number of carbon compared to compounds with number even carbon (Fig. 3). This pattern, observed in S2, S6, S9, S8, S5, and $\mathrm{S} 7$, indicates a biogenic origin generally attributed to phytoplankton [9]. The rest of the sites (S1, S3, S4, and S10)
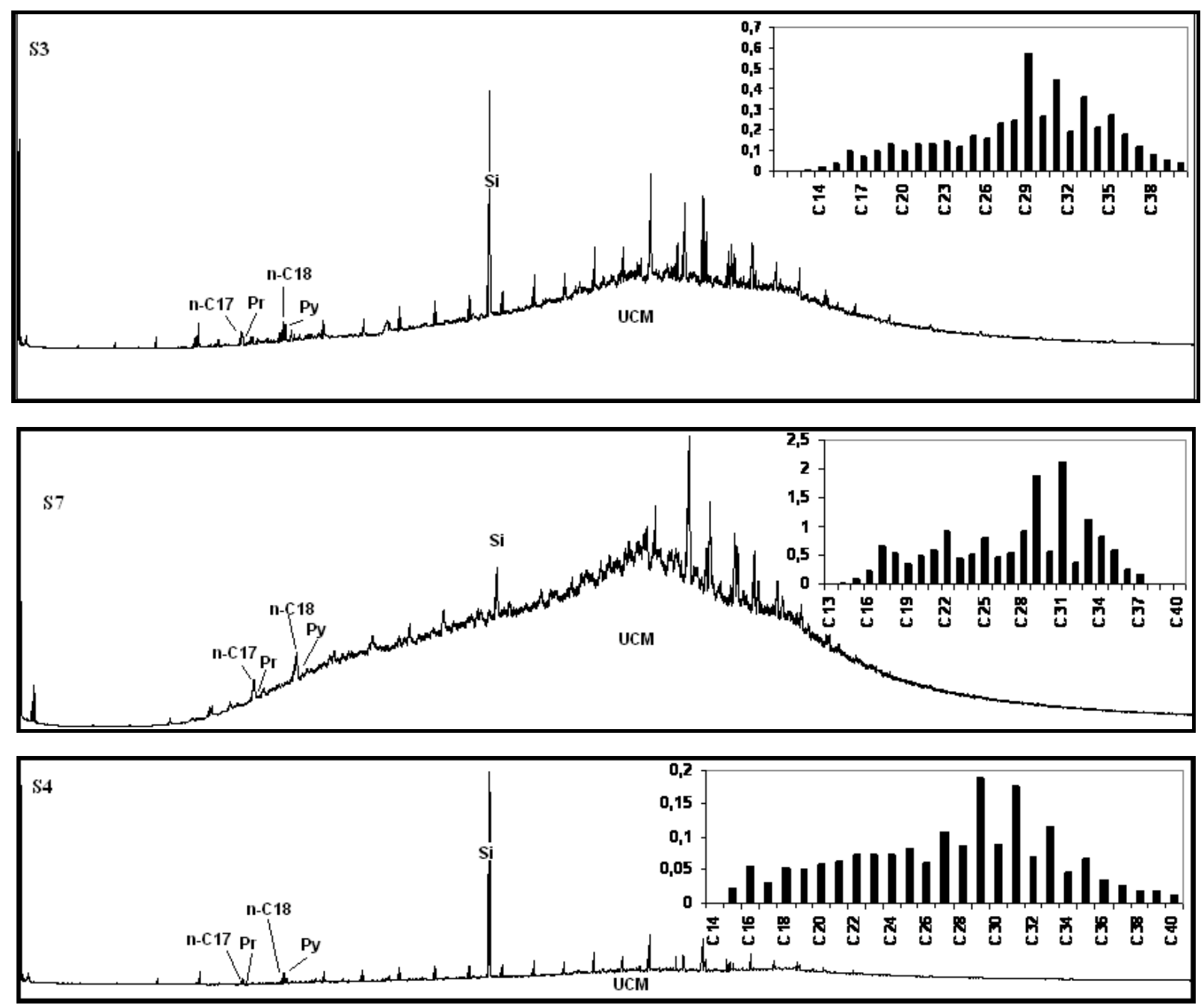

Fig. (3). Chromatograms of aliphatic hydrocarbons obtained by GC/FID for sediment samples of the Tangier's bay (example of S3, S4 and S7 stations). 
present a light predominance of compounds with even number of carbon to odd ones, which indicates bacterial origin [10].

On the other hand, for all the samples the range of heavy compounds showed important presence of the n-C27, n-C29, n-C31 compounds and sometimes n-C33, with a light predominance of odd to even number of carbon compounds (Fig. 3). This profile is generally assigned to a terrestrial biologic origin more precisely linked to the superior plants [11]. This contribution is very important compared to marine ones as it was confirmed by the $\mathrm{n}-\mathrm{C} 29 / \mathrm{n}-\mathrm{C} 17$ ratio, superior to the unit (Table 1) [12].

Nevertheless, the CPI index calculated for all analyzed samples varied around the unit $(0.62$ to 1.70$)$, indicating a contribution of oil origin (Table 1) [13].

\subsubsection{Isoprenoid Compounds}

The isoprenoid alkanes, pristane (Pr) and phytane $(\mathrm{Ph})$, were present in all sediment samples. Their presence in important quantity relatively to the normal alkanes is considered commonly like an indication of oil contamination [14]. So, the $\mathrm{Pr} / \mathrm{Ph}, \mathrm{n}-\mathrm{C} 17 / \mathrm{Pr}$ and $\mathrm{n}-\mathrm{C} 18 / \mathrm{Ph}$ ratios have been described to characterize the origins and the degree of deterioration of the hydrocarbons. For the uncontaminated sediments the $\mathrm{Pr} / \mathrm{Ph}$ is higher than 1 [15], which is the case for two samples relative to S10 and S5 stations (Table 1) indicating a biologic origin. For the other samples the $\mathrm{Pr} / \mathrm{Ph}$ ratio was lower than 1 indicating oil contamination traces [16].

The $\mathrm{n}-\mathrm{C} 18 / \mathrm{Ph}$ ratio is more specific to oil products than the $\mathrm{n}-\mathrm{C} 17 / \mathrm{Pr}$, [17]. Accordingly, the S2 present a low $\mathrm{n}-\mathrm{C} 18 / \mathrm{Ph}$ ratio indicating a degraded material of petrogenic hydrocarbons. On the other hand, S7 sample show a ratio well superior to the unity indicating the oil origin whereas the rest samples presents characteristic ratios of a degraded biogenic material $(0.5<\mathrm{C} 18 / \mathrm{Ph}<2.1)$.

\subsubsection{Hopanes}

These compounds were also identified in all samples of sediments (Fig. 4). They are present in series of 27 to 35 atoms of carbon, with a configuration $17 \alpha(\mathrm{H}), 21 \beta(\mathrm{H})$. Besides, the compounds of 31 to 35 atoms of carbon are present in doublet of epimeres $22 \mathrm{R}$ and $22 \mathrm{~S}$. This pattern characterizes an oil contamination [18].

\subsection{Zone 2 (Kabila - Kaâ Sras)}

The chromatographic results linked to aliphatic hydrocarbons are shown in Table 2. Concentrations of aliphatic hydrocarbons varied from 5.25 to $22.71 \mu \mathrm{g} / \mathrm{g}$ dry weights. The spatial distribution of aliphatic hydrocarbons concentrations (Fig. 5) shows enrichment that appears respectively at the stations S3 and S5 corresponding to the coastline of Martil and to the mouth of the Oued Laou river. This enrichment is probably related to their localization close to the evacuations of wastes at the mouths of the Martil and Oued Laou rivers.

\subsection{1. $U C M$}

These unresolved compounds were found at low levels $(1.37-4.77 \mu \mathrm{g} / \mathrm{g})$ in the samples (Table 2). These compounds, corresponding to branched and cyclic hydrocarbons, are usually assigned to products of oil or algae degradation. As shown in Table $\mathbf{2}$, the ratio of the unresolved compounds to resolved ones $(\mathrm{U} / \mathrm{R})$, calculated for all samples analyzed $(0.2-0.7)$ indicated the presence of degraded algal material or micro-organisms [19].

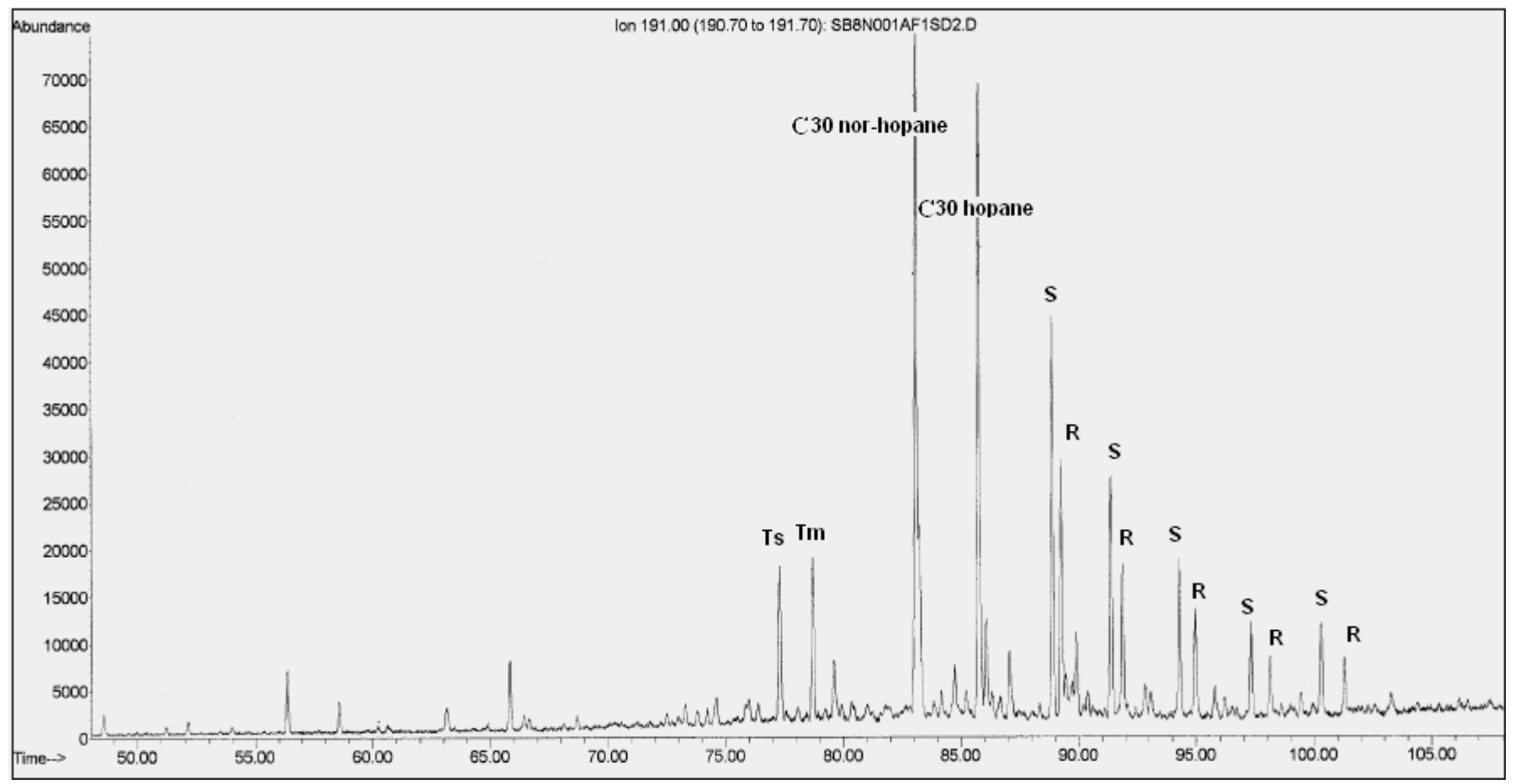

Fig. (4). Characteristic mass fragmentation for $\mathrm{m} / \mathrm{z} 191$ from the GC/MS for samples from zone 1. (Ts: 18 $\alpha(\mathrm{H})-22,29,30$-trinorneohopane; Tm: 17 $\alpha(\mathrm{H})-22,29,30$-trinorhopane, C29: 17 $\alpha(\mathrm{H}), 21 \beta(\mathrm{H})$ 29-norhopane, Hopane; (C31-C35): hopanes series with 22S and 22R epimers). 
Table 2. Aliphatic Hydrocarbons Concentrations and Selected Aliphatic Diagnostic Criteria for the Sediments Collected from Zone 2

\begin{tabular}{|c|c|c|c|c|c|c|c|c|c|c|}
\hline & NAH & UCM & T-alk & U/R & CPI & \%C>25 & C29/C17 & Pr/Ph & C17/Pr & C18/Ph \\
\hline \hline St-1 & 6.86 & 3.02 & 0.31 & 0.79 & 1.06 & 66.54 & 10.19 & -- & -- & -- \\
\hline St-2 & 6.97 & 2.29 & 0.47 & 0.49 & 0.91 & 81.48 & 40.47 & -- & -- \\
\hline St-3 & 15.52 & 4.77 & 1.96 & 0.44 & 1.41 & 68.26 & 111.39 & -- & -- & -- \\
\hline St-4 & 5.25 & 1.37 & 0.72 & 0.35 & 2.27 & 79.04 & 114.08 & -- & -- & -- \\
\hline St-5 & 22.71 & 4.41 & 10.03 & 0.24 & 1.18 & 38.33 & -- & -- & -- & - \\
\hline St-6 & 9.27 & 3.65 & 1.37 & 0.65 & 2.39 & 72.68 & 45.55 & 0.43 & 1.80 & 2.04 \\
\hline
\end{tabular}

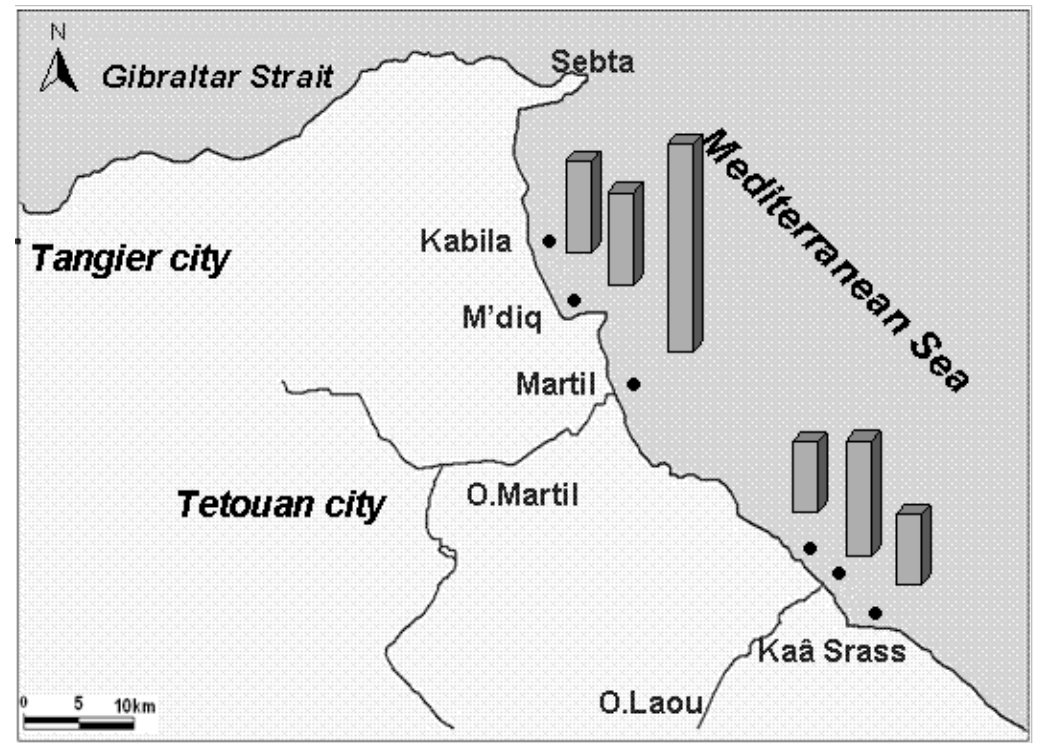

Fig. (5). Map showing spatial distribution of aliphatic hydrocarbons rates presented in logarithmic scale in the fringe between Kabila and Kaâ Srass.

\subsubsection{N-Alkanes}

The concentrations of total n-alkanes varied from 0.4 to $1.9 \mu \mathrm{g} / \mathrm{g}$ with the exception of a maximum of $10 \mu \mathrm{g} / \mathrm{g}$ at the site located in the mouth of the Oued Laou river (S5). The distribution of n-alkanes (n-C15-n-C35) was dominated by heavy compounds having a number of carbon superior to 25 (\% C $>25$ constitutes $62-72 \%$ of total n-alkanes) except for S5 station.

The distribution pattern presents a mode centred on the n$\mathrm{C} 29$ and the n-C31 and presents a light predominance of odd over even carbons compounds (Fig. 6). This motif is linked to continental biologic origins (superior plants) [20]. The linear alkanes, usually linked to biologic marine origins (n-C15, n-C17, n-C18 and n-C19), are present in low concentrations and for some samples they are absent.

On the other hand, the CPI values suggest for most samples the presence of an oil contamination traces $(\mathrm{CPI} \approx 1)$. However, a bacterial contribution can not be excluded.

The S4 and S6 stations corresponding respectively to the coastlines of Oued Laou and Kaâ Sras presented values of CPI of 2.27 and 2.39. Even if these values are superior to 1, they remain, however, lower to what is assigned to a terrestrial signature $(\mathrm{CPI}=3)$.

\subsubsection{Isoprenoid Compounds}

Pristane and phytane compounds were not detected in all samples, except for Kaâ Srass station (S6) where the $\mathrm{Pr} / \mathrm{Ph}$ ratio is much lower than 1 (Table 2 ) indicating the presence of degraded petrogenic products. The $\mathrm{C} 17 / \mathrm{Pr}$ and $\mathrm{C} 18 / \mathrm{Ph}$ ratios were respectively of 1.8 and 2.04 (Table 2) suggesting a biological origin.

\subsubsection{Hopanes}

The analysis reveals the presence of hopanes in series of 27-34 atoms of carbon. Those compounds have the thermodynamically stable configuration $17 \alpha(\mathrm{H}), 21 \beta(\mathrm{H})$ and show a maximum in $\mathrm{C} 29$ and in $\mathrm{C} 30$ (Fig. 7). Such signature confirms the presence of mature oil in the sediments [18]. Besides, the C31-C34 hopanes are present as epimeres of $22 \mathrm{~S}$ and $22 \mathrm{R}$. On the other hand, the analysis also showed the presence of the diploptene compound which has been linked to a bacterial origin [21] and/or a terrestrial origin [22].

\section{DISCUSSION}

This assessment of the hydrocarbons levels permitted to show up the importance of hydrocarbons introduced especially on Tangier's bay and accumulated in sediments. 

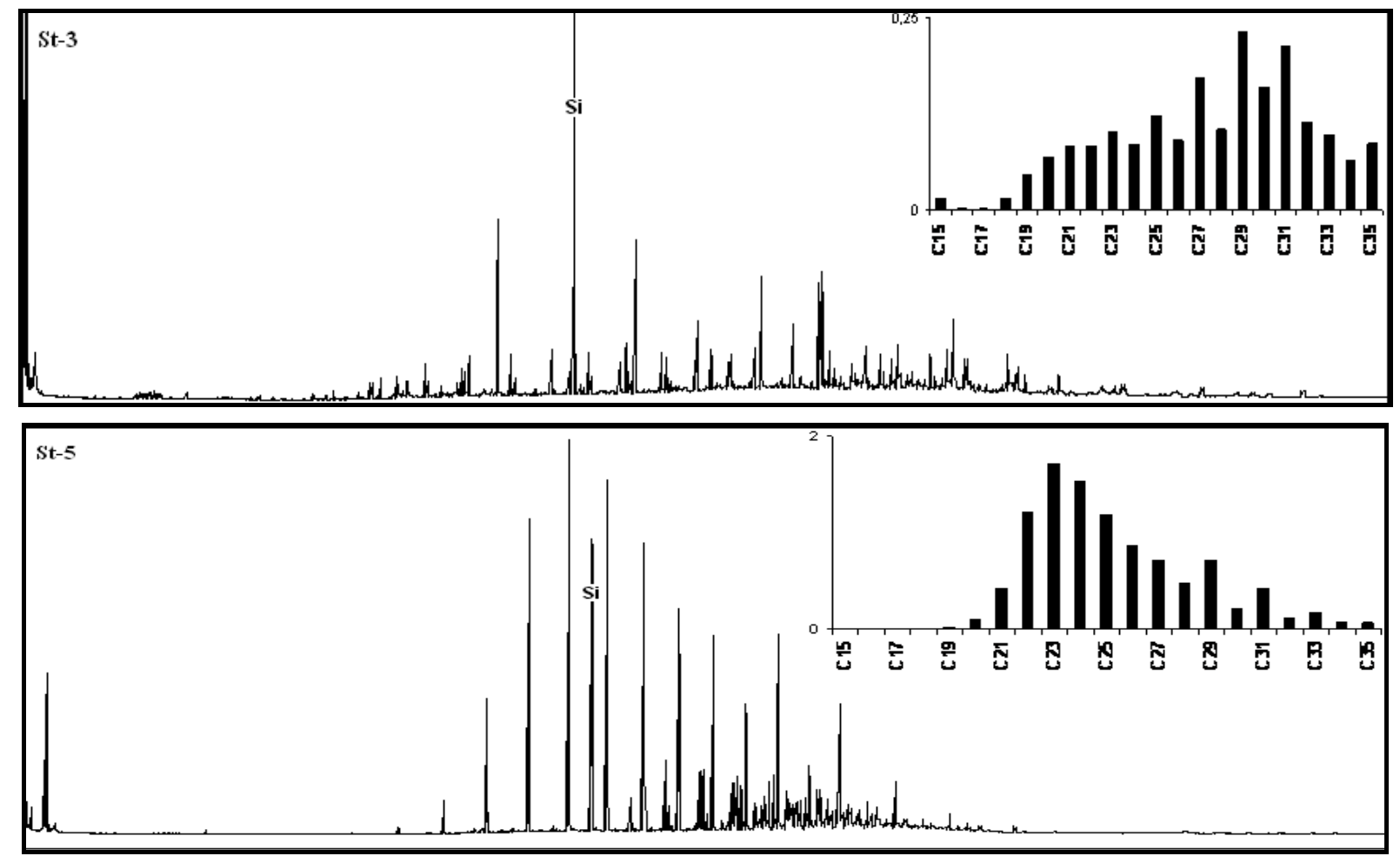

Fig. (6). Chromatograms of aliphatic hydrocarbons obtained by GC/FID for sediment samples from the fringe between Kabila and Kaâ Srass (example of St-3 and St-5 stations).

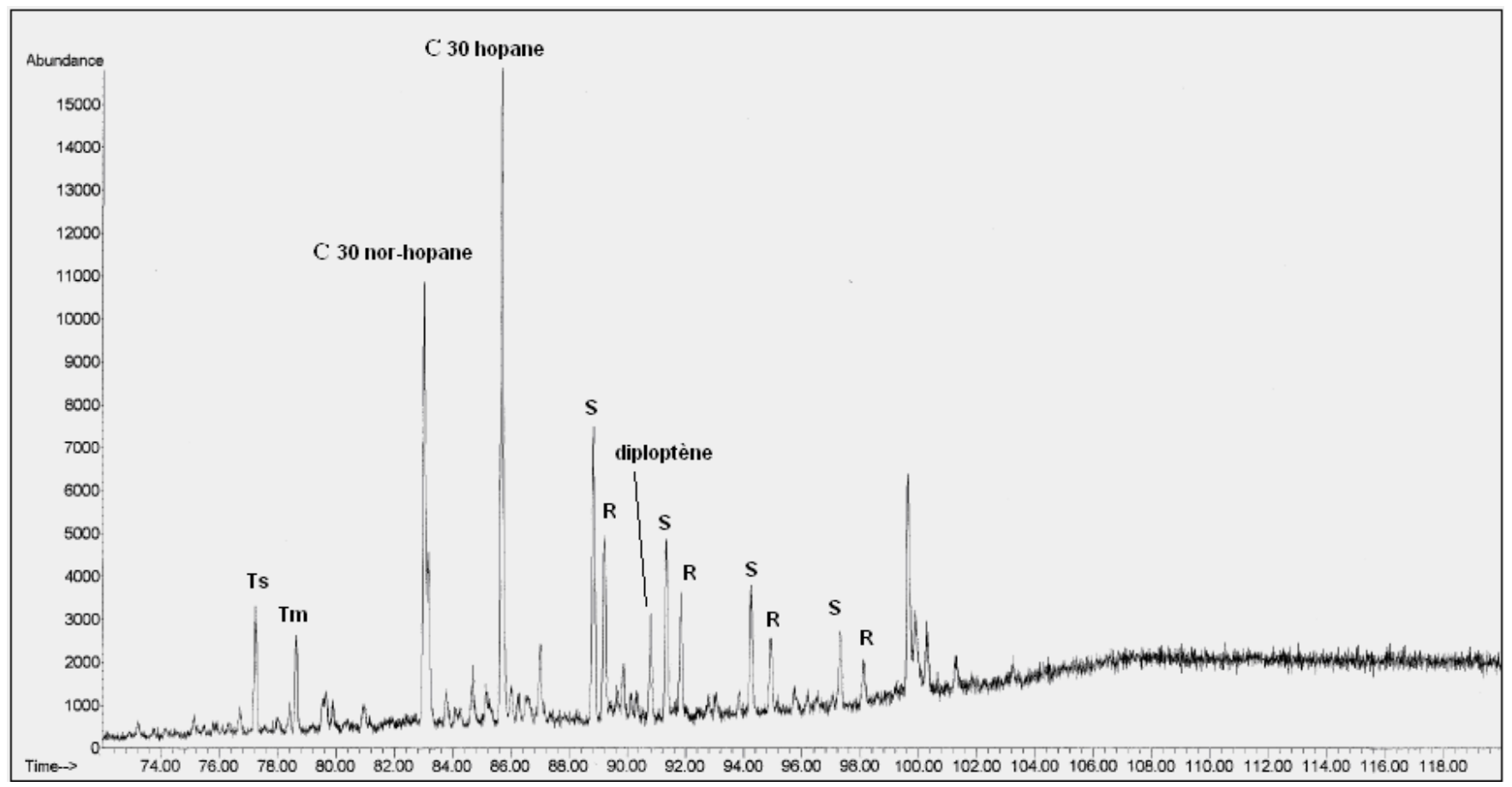

Fig. (7). Characteristic mass fragmentation for $\mathrm{m} / \mathrm{z} 191$ from the GC/MS for samples from zone2. (Ts: 18 $\alpha(\mathrm{H})-22,29,30$-trinorneohopane; Tm: 17 $\alpha(\mathrm{H})-22,29,30$-trinorhopane, C29: 17 $\alpha(\mathrm{H}), 21 \beta(\mathrm{H})$ 29-norhopane, Hopane; (C31-C35): hopanes series with 22S and 22R epimers).

Sediments collected from this area showed high accumulation of aliphatic hydrocarbons. In comparison with the results from other sites of the Mediterranean, these concentrations are similar to those reported for the Delta of the Rhone [23]. However, they remained lower than those reported for some Mediterranean environments chronically polluted, such as the Alexandria harbour, Egypt (60.7-1356.3 $\mu \mathrm{g} / \mathrm{g})[24]$ and the Northern (349 in $1983 \mu \mathrm{g} / \mathrm{g}$ ) and Southern $(310-1406 \mu \mathrm{g} / \mathrm{g})$ coasts of Sfax, Tunisia $[25,26]$.

On the other hand, the concentrations of aliphatic hydrocarbons reported for the sediments collected from the coastal zone between Kabila and Kaâ Srass seems to be 
much lower than the levels reported for the Tangier's bay. However, similar concentrations were found in other Mediterranean zones such as in the Sea of Crete in Eastern Mediterranean (0.56-5.69 $\mu \mathrm{g} / \mathrm{g})$ [27].

The examination of aliphatic hydrocarbons distribution in sediments for Tangier's bay as well as for the Mediterranean fringe appears to be controlled by multiple factors. First of all, we can mention the proximity to continental sources of pollution. Those areas are extremely exposed to anthropogenic pressure from the cities of Tangier and Tetouan. Indeed those coasts receive continually an important amount of urban wastes (domestic and industrial ones). On the other hand, these coasts have an important touristic activity, generating considerable amounts of pollutants which are poured into the littoral zone.

In addition, many harbours are located in those areas (zone 1 and zone 2). As a consequence, the distribution of aliphatic hydrocarbons levels is strongly affected by harbour's activities of fishing, transport and navigation.

The oceanographic factors can not be excluded, since they contribute efficiently in the distribution of aliphatic hydrocarbons along the sediments of the zone, as clearly demonstrated in this study. Indeed, Tangier's bay constitutes a relatively closed environment with limited hydrodynamic activity; accordingly the evacuation of the pollutants introduced in this environment seems to be a difficult task. Thus pollutants are mostly absorbed on the particles in suspension and have time enough to be incorporated to the sediments where they are accumulated and preserved. Accordingly, the bay seems to be more affected than the coastal fringe KabilaKaâ Srass which corresponds to a relatively open environment where water circulation is responsible of the patchiness of particulates and sediments and thus of pollutants.

All those combined factors seem to influence also the composition of this fraction of hydrocarbons. Thus, the relatively semi enclosed environment of Tangier's bay, which receives continually anthropogenic inputs from the city and the harbour exhibited trends to accumulate and preserve the pollutants. That explains the predominant petrogenic signature, as follows from the chromatographic analysis, over the biogenic traces. In fact, the detailed examination of the composition of all the samples from this area shows patterns related to petrogenic origins mainly in stations situated in the western part of the bay (S1, S2, S7) and close to the anthropogenic sources (wastes and harbour).

This origin is traduced first by the presence of UCM in the range of heavy compounds, the decrease of concentrations of n-alkanes according to the number of carbon since $\mathrm{n}-\mathrm{C} 35$, the presence of isoprenoid compounds presenting ratios lower then the unity with an indication of raw oil at S7 station (inside the harbour) and finally by the pattern of hopane series with $\alpha \beta$ configuration and epimeres in $22 \mathrm{~S}$ and 22R for the compounds C31-C35.

On the other hand, biogenic origins are also verified mainly by n-alkanes composition and distribution. It traduces a bacterial origin especially at stations close to urban wastes (S3, S4) indicated by the relatively important presence of $\mathrm{n}-\mathrm{C} 18$ with a light predominance of the even compounds whereas phytoplankton traces are traduced by $\mathrm{n}-\mathrm{C} 17$ and/or $\mathrm{n}-\mathrm{C} 15$ with a slight predominance of odd compounds. The major presence of $n-C 27, n-C 29$ and $n-C 31$ in all stations is strongly related to a terrestrial biogenic origin linked to superior plants.

Contrarily, the aliphatic hydrocarbons of the fringe Kabila-Kaâ Srass (relatively open environment) showed relatively different patterns. The composition traduces a predominant presence of biogenic signature mostly linked to bacterial and terrestrial origins. In addition, n-alkanes showed no predominance between odd and even compounds in the range of the lower molecular weight compounds which is usually linked to a bacterial origin. The continental origin relative to superior plants is strongly prevailing. It is traduced by the maximums of n-C27, n-C29 and n-C31. Those biogenic origins were also suggested by the presence of a diploptene compound.

The petrogenic source is slightly observed for this zone, inversely to the Tangier's bay. It was essentially signalled by the presence of the hopanes in series of C27-C34/C35 with $\alpha \beta$ configuration and the epimeres in $22 \mathrm{~S}$ and $22 \mathrm{R}$ for the C31-C35 compounds.

Furthermore and unlike Tangier's bay case, the isoprenoid compounds $\mathrm{Pr}$ and $\mathrm{Ph}$ are absent in all samples except in Kaâ Srass station (S6) where the $\mathrm{Pr} / \mathrm{Ph}$ ratio translate a degraded petrogenic products. However, the $\mathrm{C} 17 / \mathrm{Pr}$ and $\mathrm{C} 18 / \mathrm{Ph}$ ratios traduce a degraded biologic material.

From the results obtained, it follows that anthropogenic impacts are more important in the bay (zone 1) than the fringe (zone 2), even if the amounts of pollutants released to the littoral in this zone are quite significant. So, it seems that the morphology and marine circulation combined to physicochemical conditions can influence the rates of accumulation as well as the composition of aliphatic hydrocarbons. A semi closed environment present conditions of water circulation relatively delimited allowing the installation of good conditions of preservation and accumulation (Tangier's bay case), contrarily to an open environment where the marine circulation is more intense and agitated permitting a good dispersion of pollutants (fringe case).

\section{CONCLUSION}

The Moroccan Mediterranean coastline is stressed by both domestic and industrial wastes, harbour activities, and urbanisation and fishing activities. The drained polluting load is important in quantity.

This survey has provided very important conclusions about the contamination of Mediterranean Western coasts of Morocco by aliphatic hydrocarbons. In comparison with other sites chronically contaminated, the study areas show important levels of aliphatic hydrocarbons concentration still not alarming.

This work has shown also the important influence of oceanographic and hydrodynamic factors in the distribution of hydrocarbons levels. Accordingly, the bay of Tangier which constitutes an environment relatively calm and semiclose is more affected by hydrocarbon inputs, inversely to the coasts between Kabila and Kaâ Srass.

Furthermore, the qualitative and quantitative analysis points out two important origins of hydrocarbons: biogenic 
and anthropogenic. First of all, the natural source was related to phytoplankton, bacteria and continental plants, while the anthropogenic source was related to petrogenic inputs, fishing and navigation activities, as well as to urban wastes originated in close agglomerations.

\section{CONFLICT OF INTEREST}

None declared.

\section{ACKNOWLEDGEMENT}

None declared.

\section{REFERENCES}

[1] Sumok P. Riverwater quality monitoring: sharing Sarawak experience. In: Proc. 6th Sabah Inter-Agency Tropical Ecosystem (SITE) Research Seminar; Kota Kinabalu, Malaysia 2001; p. 4.

[2] Phiri O, Mumba P, Moyo BHZ, Kadewa W. Assessment of the impact of industrial effluents on water quality of receiving rivers in urban areas of Malawi. Int J Environ Sci Technol 2005; 2: 237-44.

[3] Burns KA, Saliot A. Petroleum hydrocarbons in the Mediterranean Sea: a mass balance. Mar Chem 1986; 20: 141-57.

[4] Hopkins TS, eds. Physical processes in the Mediterranean basins. In estuarine transport processes. Kjerfve B., South Carolina, Columbia 1978; pp. 269-310.

[5] UNEP. Les perspectives du Plan Bleu sur l'environnement et le développement: Prospective 2025 pour un développement durable du bassin méditerranéen, Rapport. Programme des Nations Unies pour l'Environnement 2005; p. 427.

[6] Bilardo U, Mereddu G, Eds. La pollution par hydrocarbures dans la mer Méditerranée in trafic pétrolier et environnement durable, Clean up the Med 2007.

[7] Belcaid S. Biodiversité dans la zone maritime détroit de Gibraltar et Méditerranée occidentale, Journée mondiale de la terre, tanger 2010.

[8] CSEC. Eds. Réutilisation des eaux usées en agriculture. Conseil Supérieur de l'eau et du climat, Rabat, Maroc 1994; p. 88.

[9] Metcalf and Eddy. Wastewater engineering. Treatment Disposal Reuse. New York: McGraw-Hill Publishers, Tchobanoglous G, Burton FL. 1991; p. 1820.

[10] Bouzid S, Andaloussi H, Aboumaria K, Er-Raioui H. Urban effluent pollution from the Mghogha flow of the west, margin of the Mediterranean Sea, Morocco. Afr J Environ Sci Technol 2008; 2: $116-23$

[11] Grommaire-Mertz MC. La pollution des eaux pluviales urbaines en réseau d'assainissement unitaire, Caractéristiques et origines. Thèse de doctorat de l'Ecole nationale de ponts et chaussées 1998; p. 477.

[12] Rodier J, Ed. L'analyse de l'eau: eaux naturelles, eaux résiduaires, eau de mer: physico-chimie, bactériologie et biologie. Dunod, Paris, France 1996; p. 1383.

[13] Blinda M. Pollution tellurique du littoral nord-ouest du Maroc entre Tanger et Tétouan: Caractérisation, Impact sur l'Environnement et Proposition de Solutions, thèse de doctorat, Université Mohammed V- Rabat (Maroc) 2007; p. 162.

[14] Bloundi K. Etude géochimique de la lagune de Nador (Maroc oriental): Impacts des facteurs anthropiques, thèse de doctorat, Thèse en cotutelle Ecole et Observatoire des Sciences de la Terre Centre de Géochimie de la Surface (UMR 7517) (France) et Université Mohamed V- Agdal (Maroc) 2005; p. 198.

[15] MEM. Eds. Normes marocaines. Bulletin officiel du Maroc (5062 du 30 ramadan 1423). Ministère de l'Aménagement du Territoire, de l'Eau et de l'Environnement. Rabat 2002.

[16] Nisbet Verneaux J. Composantes chimiques des eaux courantes. Discussion et proposition de classes entant que bases d'interprétation des analyses chimiques. Ann Limnol 1970; 6: 1619.

[17] Ericksson E, Auffarth K, Henze M, Ledin A. Characteristics of grey wastewater. Urban Water 2002; 4: 85-104.

[18] Gray SR, Becker NSC. Contaminant flows in urban residential water systems. Urban Water 2002; 4: 331-46.
[19] Dyer SD, Peng C, Mcavoy DC, et al. The influence of untreated wastewater to aquatic communities in the balatuim River, the Philippines, Pergamon. Chemosphere 2003; 52: 43-53.

[20] Waksman SA. Humus, Origin, chemical composition and importance in nature. Baltimore: Williams and Wilkins Co.1938; pp. 526.

[21] EL Hatimi I, Achab M, EL Moumni B. Impact des émissaires et canalisation sur l'environnement de la baie de Tanger (Maroc) : approche géochimique. Bulletin de l'Institut scientifique, Rabat. Sec Sci de la Terre 2002; 24: 49-58.

[22] Manskaya SM, Drozdova TV, Geochemistry of organic substances. Shapiro L \& Breger IA Eds. Oxford Press, Pergamon 1968; p. 345.

[23] Rashid MA, Leonard JD. Modifications in the solubility and precipitation behaviour of various metals as a result of their interaction with sedimentary humic acids. Chem Geol 1973; 11: 89-97.

[24] Thomas O. Ed. Métrologie des eaux résiduaires. Cebedoc Lavoisier/Tec et Doc 11 Liège -Paris 1995; p. 192.

[25] Berner R. Sedimentary pyrite formation: an update. Geochim. Cosmochim Acta 1984; 48 (4): 605-15.

[26] Benkhokroun $M$, Bouchama $M$. La réutilisation des eaux usées en agriculture au Maroc. In: VII congrée mondial des ressources en eau, gestion des ressources en eau, Rabat. 1993; pp. 13-18.

[27] Henze M, Harremoes P. Eds. Wastewater treatment. biological and chemical processes. La Cour Jansen J. and Arvin, Berlin 1997; 143-92.

[28] Sponza DT. Application of toxicity tests into discharges of the pulp-paper industry in Turkey. Ecotox Environm Safe 2003; 54: 74-86.

[29] Luoma SN. Bioavailability of trace metals to aquatic organisms. A Review Sci Total Environ 1983; 28: 1-22.

[30] Tissot B, Welte DH, Eds. Petroleum formation and occurence, a new approach to oil and gaz exploration. Springer Verlag 1978; p. 538.

[31] Tissot BP, Pelet R, Roucaché J, Combaz A. Eds. Utilisation des alcanes comme fossiles géochimiques indicateurs des environnement géologiques. In: Adv. Org. Geochem, Campos R, GONI J. Madrid España 1975; 117-54.

[32] Welte DH. Petroleum exploration and organic geochemistry. J Geochem Explor 1972; 1: 117-36.

[33] Er-Raioui H, Bouzid S, Marhraoui M, Saliot A. Hydrocarbon pollution of the Mediterranean coastline of Morocco. Ocean Coast Manage 2009; 52: 124-9.

[34] Bouzid S, Er-Raioui H, Saliot A, Bouloubassi I, Marhraoui M. International Congess of Biochemistry. Contamination de la frange littorale de Tétouan par les hydrocarbures. Agadir 2006.

[35] Bouzid S. Etat de la contamination des côtes ouest de la mediterrannee par les hydrocarbures / baie de Tanger et frange littorale «fnideq-kaâ srass», thèse de doctorat, Université Abdelmalek Essâadi (Maroc), 2007; p. 167.

[36] Bouzid S, Khannous S, Bouloubassi I, Saliot A and Er-Raioui H. Assessment of the Mediterranean Moroccan coasts contamination by hydrocarbons (NAH, AH and Alkylbenzenes). Int J Geosci 2011 (in press).

[37] Desmukh ARAS, Gumaste VK and Bhawal BM. Alkilation of bnzene with long chain (C8-C18) linear primary alcohols over zeolite-Y. Cata Letters 2000; 64 (2-4): 247-50.

[38] Medeiros PM, Bicego MC, Castelao RM, et al. Natural and anthropogenic hydrocarbon inputs to sediments of Patos Lagoon Estuary, Brazil. Envirom Int 2005; 31 (1): 77-87.

[39] Tsutsumi S, Yamaguchi Y, Nishida I, et al. Alkylbenzenes in mussels from South and South East Asian coasts as a molecular tool to assess sewage impact. Mar Poll Bul 2002; 45 (1): 325-31.

[40] Isobe KO, Zakaria MP, Chiem NH, et al. Distribution of linear alkylbenzenes (LABs) in riverine and coastal environments in South and Southeast Asia. Water Res 2004; 38 (9): 2449-59.

[41] Takada H, Ishiwatari R. Linear alkylbenzenes in urban riverine environments in Tokyo: distribution, source, and behavior. Environ Sci Technol 1987; 21 (9): 875-83.

[42] Crisp PT, Brenner S, Venkatesan MI, et al. Organic chemical characterization of sediment-trap particles from San Nicolas, Santa Barbara, Santa Monica and San Pedro Basins, California. Geochim. Cosmochim Acta 1979; 43 (11): 1791-801.

[43] Takada H, Ogura N, Ishiwatari R. Distribution of linear alkylbenzenes (LABs) and linear alkylbenzene sulfonates (LAS) in 
Tokyo Bay sediments. Estuarine Coast Shelf Sci 1992; 35 (2): 14156.

[44] Chalaux N, Takada H, Bayona JM. Molecular markers in Tokyo Bay sediments: sources and distribution. Mar Envir Res 1995; 40 (1): 77-92.

[45] Serrazanetti GP, Pagnucco C, Conte LS, Artusi R. Aliphatic hydrocarbons and linear alkylbenzenes in zooplankton from the Gulf of Trieste. Chemosphere 1994; 28 (6): 1119-26.

[46] Bordin G. Distribution et évolution saisonnière du cuivre dissous dans un écosystème estuarien macrotidal d'Europe occidentale (estuaire de l'Aulne, France). Oceanologica Acta 1991; 14: 445-56.

[47] Stitou M, Dolores Galindo M, El Mai H, et al. Etude relative à l'évaluation de la contamination métallique dans la plage de la ville de Tanger, Les cahiers de la recherche de l'Université Abdelmalek Essaadi 2010; 1 (4-5): 39-48.

[48] Kaimoussi A. Etude de la variabilité de l'accumulation des métaux lourds dans les différents compartiments (sec, mollisque et algue) du littoral de la région d'El Jadida, thèse de doctorat, université Chouaib Doukhali, El Jadida, Maroc 1996; p. 138.

[49] Koukal B, Dominik J, Vignati D, et al. Assessment of water quality and toxicity of polluted Rivers Fez and Sebou in the region of Fez (Morocco). Environ Poll 2004; 131: 163-72.
[50] Azzaoui S, El Hanbali M, Leblanc M. Copper, lead, iron and manganese in the Sebou drainage basin: sources and impact on surface water quality. Water Qual. Res J 2002; 37 (4): 773-84.

[51] Baghdad K., Bendraoua A. Traitement, étude, impact des effluents liquides sur le littoral de l'Ouest algerien. 2ème colloque international «Biodiversité et Ecosystèmes littoraux», Oran, Algeria 2010; p. 353-7.

[52] Kais BH, Bouras D, Boutiba Z. Surveillance et évaluation de la qualité de la biodiversité des milieux et des habitats côtiers (côte oranaise, Algérie nord occidentale). 2ème colloque international «Biodiversité et Ecosystèmes littoraux », Oran, Algeria 2010; p. 61.

[53] Mennad M, Bachari NEI. Approche SIG pour l'analyse spacialte de la pollution marine dans la baie d'Alger. 2ème colloque international «Biodiversité et Ecosystèmes littoraux », Oran, Algeria 2010; p. 59.

[54] Illou S. Impacts des rejets telluriques d'origines domestique et industrielle sur les environnements côtiers: cas du littoral Nord de la ville de Sfax (Tunisie), Thèse de doctorat, Université de Tunis II (Tunisie), 1999; p. 259.

[55] Zaghden H, Kallel M, Louati A, Elleuch B, Oudot J, Saliot A. Hydrocarbons in surface sediments from the Sfax coastal zone (Tunisia) Mediterrranean Sea. Mar Poll Bul 2005; 50: 1287-94.

(C) Bouzid et al.; Licensee Bentham Open.

This is an open access article licensed under the terms of the Creative Commons Attribution Non-Commercial License (http://creativecommons.org/licenses/by$\mathrm{nc} / 3.0 /$ ), which permits unrestricted, non-commercial use, distribution and reproduction in any medium, provided the work is properly cited. 